\title{
Redd1 Is a Novel Marker of Testis Development but Is Not Required for Normal Male Reproduction
}

\author{
A.J. Notini ${ }^{a, b}$ P.J. McClive ${ }^{a}$ S.J. Meachem ${ }^{c} \quad$ J.A. van den Bergen ${ }^{a}$ \\ P.S. Western ${ }^{a}$ b S.E. Gustin ${ }^{a}$ V.R. Harley ${ }^{c}$ P. Koopman ${ }^{d}$ A.H. Sinclair ${ }^{a}$ \\ a Murdoch Children's Research Institute and Department of Paediatrics, University of Melbourne, \\ Royal Children's Hospital, Melbourne, Vic., ${ }^{b}$ Monash Institute of Medical Research, Monash University, \\ 'Prince Henry's Institute of Medical Research, Clayton, Vic., and dInstitute for Molecular Bioscience, \\ University of Queensland, Brisbane, Qld., Australia
}

\section{Key Words}

Gonadogenesis • Murine $\cdot$ Redd1 • Sex determination • Testis

\begin{abstract}
In an effort to identify novel candidate genes involved in testis determination, we previously used suppression subtraction hybridisation PCR on male and female whole embryonic (12.0-12.5 days post coitum) mouse gonads. One gene to emerge from our screen was Redd1. In the current study, we demonstrate by whole-mount in situ hybridisation that Redd1 is differentially expressed in the developing mouse gonad at the time of sex determination, with higher expression in testis than ovary. Furthermore, Redd1 expression was first detected as Sry expression peaks, immediately prior to morphological sex determination, suggesting a potential role for Redd1 during testis development. To determine the functional importance of this gene during testis development, we generated Redd1-deficient mice. Morphologically, Redd1-deficient mice were indistinguishable from control littermates and showed normal fertility. Our results show that Redd1 alone is not required for testis development or fertility
\end{abstract}

in mice. The lack of a male reproductive phenotype in Redd1 mice may be due to functional compensation by the related gene Redd2.

Copyright $\odot 2012$ S. Karger AG, Base
The key sex-determining gene in most mammals is the Y-linked gene Sry (sex-determining region on the Y chromosome) [Sinclair et al., 1990]. In the mouse, Sry is expressed briefly in the pre-Sertoli cells of the genital ridge from 10.5 days post coitum (dpc) to $12.5 \mathrm{dpc}$ and this initiates testis determination and differentiation [Koopman et al., 1990]. The genetic pathways downstream of Sry that further regulate testis formation and differentiation, however, remain largely unknown. In an effort to identify novel genes involved in these pathways, we previously performed a differential expression screen, which revealed 54 transcripts that were upregulated in embryonic mouse testis at $12.0-12.5 \mathrm{dpc}$. This included 8 genes that were novel or of unknown function [McClive et al., 2003].

One gene to emerge from our screen was Redd1 (regulated in development and DNA damage responses 1). Male-specific up-regulation of Redd1 in the gonad at 12.5

\section{KARGER}

Fax +4161306 1234

E-Mail karger@karger.ch

www.karger.com (c) 2012 S. Karger AG, Basel

$1661-5425 / 12 / 0065-0223 \$ 38.00 / 0$

Accessible online at:

www.karger.com/sxd
Andrew Sinclair

Murdoch Children's Research Institute

Royal Children's Hospital, Flemington Rd

Melbourne, VIC 3052 (Australia)

Tel. +61 38341 6424, E-Mail andrew.sinclair@mcri.edu.au 
dpc was confirmed by whole-mount in situ hybridisation (WISH). Furthermore, within the gonad, Redd1 expression localised to the testis cords suggesting that this gene might play a role in male sex determination or early differentiation of the testis.

Previous studies reported that Redd1 (also known as RTP801, Ddit4 and Dig2) showed strong up-regulation in response to a variety of cellular stressors, including hypoxia, DNA damage and glucocorticoid treatment [Ellisen et al., 2002; Shoshani et al., 2002; Wang et al., 2003]. The Redd1 gene encodes a widely expressed, highly conserved, low-molecular-mass protein that contains no known structural domains or functional motifs [Ellisen et al., 2002; Shoshani et al., 2002]. Redd1 has been described as a transcriptional target of HIF-1 $\alpha$ (hypoxiainducible factor 1 alpha) that can act as a pro- or antiapoptotic factor, depending on the cellular type [Shoshani et al., 2002]. It has also been described as a transcriptional target of the tumour suppressor genes, p53 and p63, involved in p53-dependent DNA damage response and p63-dependent epithelial differentiation [Ellisen et al., 2002]. Furthermore, Redd1 has been shown to act as a negative regulator of the mammalian target of rapamycin (mTOR) pathway which controls cell growth and proliferation by modulating the activity of the tuberous sclerosis tumour suppressor complex [Brugarolas et al., 2004; Corradetti et al., 2005]. A recent study has demonstrated that Redd1 is an early responsive retinoic acid target gene associated with myeloid differentiation [Gery et al., 2007]. Taken together, these findings suggest that Redd1 may potentially play a role in testis cell growth.

The Redd1 paralogue Redd2 shares approximately $50 \%$ sequence identity with Redd1, but little homology to other known proteins [Corradetti et al., 2005]. The Drosophila orthologues of Redd1 and Redd2 are termed scylla and charybdis, respectively. Scylla and charybdis act as negative regulators of growth and simultaneous loss of these genes in Drosphila results in increased susceptibility to hypoxia and mild overgrowth phenotypes [Reiling and Hafen, 2004].

Here, we present a detailed analysis of Redd1 expression during fetal testis development. Our data demonstrates that within the developing testis cords, Redd1 is expressed in the germ cells and the key testis-determining cell type, pre-Sertoli cells. Since Redd1 shows a sexually dimorphic expression pattern at the time of testis determination and is expressed in the key testis-determining cell type, we generated an in vivo model to investigate the functional importance of this gene during testis development.

\section{Materials and Methods}

\section{Whole-Mount in situ Hybridisation}

Outbred CD1 mice were used for all expression studies. WISH was carried out with digoxigenin-labelled probes, as described previously [Andrews et al., 1997; McClive and Sinclair, 2003; McClive et al., 2003]. A 320-bp RsaI cDNA fragment corresponding to Redd1 (NM_029083) was obtained from the subtraction procedure. The probes for Redd1 and Sry (NM_011564) were generated using SP6 and T7 RNA polymerases as described previously [Andrews et al., 1997; Hurley et al., 2004]. For WISH experiments using gonads from Redd1-deficient mice, the template for the 797-bp Redd1 riboprobe was generated by PCR from adult mouse spleen cDNA using the primers 5'-GGACAGCAGCAACAGTGGCT-3' and 5'-CCTGTGTGACTCCTAAGCCTT-3'. To visualise staining in sections, tissues were left in chromogen solution over 2 days at room temperature. Tissues were cryoprotected in $30 \%$ sucrose in PBS (overnight at $4^{\circ} \mathrm{C}$ ), snap frozen in OCT embedding compound and $14-\mu \mathrm{m}$ sections were cut.

\section{Redd1-Deficient Mice}

Redd1-deficient mice were generated by Ozgene Pty Ltd (Canning Vale, W.A., Australia) using the Cre/loxP system. Briefly, 3 DNA fragments (a 3.1-kb 5' homology arm containing exon 1, a $2.2-\mathrm{kb}$ floxed arm containing exons 2 and 3 and a 3.1-kb $3^{\prime}$ homology arm) were generated by nested PCR from C57BL/6 mouse genomic DNA and cloned into the pOzIII vector (Ozgene). The 5' homology arm was cloned into an $A s c I$ site, upstream of the first loxP site. The loxP arm was cloned into a SalI site upstream of the PGK-neo cassette. The $3^{\prime}$ homology arm was cloned into a KpnI site downstream of the PGK-neo cassette and the second loxP site. The targeting vector was linearised at the $3^{\prime}$ end by Not I digestion and electroporated into Bruce-4 embryonic stem cells (derived from murine strain C57BL/6J) [Kontgen et al., 1993]. Genomic DNA was isolated from individual neomycin (G418)-resistant colonies, digested with $B g l \mathrm{II}$ and screened for homologous recombination events by Southern blotting using a 450-bp $5^{\prime}$ probe. Targeted embryonic stem cell clones were microinjected into BALB/c blastocysts and transferred to pseudopregnant foster mothers. This resulted in the generation of 26 chimeric males, which were backcrossed to $P G K-C r e$ transgenic (on a C57BL/6 background) mice to confirm germline transmission and to generate heterozygous Redd1-deficient mice. Mice were maintained on a C57BL/6 background as this strain has been shown to be sensitive to sex reversal [Eicher et al., 1996]. Heterozygous Redd1-deficient mice were intercrossed in order to generate homozygous Redd1-deficient mice. Embryos were collected from timed matings, with noon of the day on which the mating plug was observed recorded as $0.5 \mathrm{dpc}$. Genomic DNA was isolated from tail biopsies of 3 -week-old mice and embryos and used as a template for multiplex PCR genotyping using primers specific for the Redd1 wild-

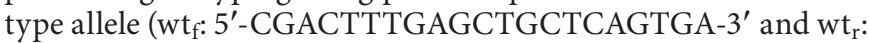
$5^{\prime}$-GCTCGGAGCTGTAGAGTTTCT-3') and the Redd1 knockout allele (kof: 5'-GCACCAGTTCGCTCACCCTT-3' and ko : $5^{\prime}$ GCCTTCTCACCTGGAGAGCA-3').

\section{Ethics Statement}

All procedures involving mice were performed with the approval of the Murdoch Children's Research Institute Animal Ethics Committee (Project Numbers A527 and A619). 
Tissue Collection, Histology and Immunofluorescence

Embryonic gonads were dissected and fixed in 4\% paraformaldehyde in PBS for $20 \mathrm{~min}$ on ice. For histological examination, tissues were embedded in paraffin, 5 - $\mu \mathrm{m}$ serial sections were cut and stained with haematoxylin and eosin (H\&E) using standard protocols. For immunofluorescence, tissues were embedded in OCT embedding compound and $10-\mu \mathrm{m}$ serial sections were cut, dried, postfixed for $1 \mathrm{~min}$ in $4 \%$ paraformaldehyde and permeabilised in 1\% Triton X-100 for $10 \mathrm{~min}$. Non-specific antibody binding was blocked in PBS containing 5\% BSA and 10\% normal goat serum overnight at $4^{\circ} \mathrm{C}$. Primary antibodies used were WT1 (Wilms tumour 1) (Santa Cruz Biotechnology, Santa Cruz, Calif., USA) diluted 1:200, laminin (Sigma, St. Louis, Mo., USA) diluted 1:200, P450scc (P450 side-chain cleavage) (Chemicon, Temecula, Calif., USA) diluted 1:400, and MVH (mouse vasa homologue) (Abcam, UK) diluted 1:10,000. Primary antibody binding was detected using goat anti-rabbit IgG conjugated to Alexa Fluor 488 (Invitrogen, Carlsbad, Calif., USA) diluted 1:500. Adult mice were killed by cervical dislocation, tissues were immediately dissected and wet weight was determined.

\section{Serum Hormone Measurements}

Concentrations of follicle-stimulating hormone (FSH) and luteinizing hormone ( $\mathrm{LH}$ ) were determined by heterologous radioimmunoassay using reagents kindly provided by Dr. Parlow at the National Institute of Diabetes and Digestive and Kidney Diseases (NIDDK, Bethesda, Md., USA). Iodinated preparations and antisera used in the FSH and LH radioimmunoassays were: rFSH-I-9 and anti-rFSH-S-11; and rLH-I-9 and anti-rLH-S-10, respectively. Results are expressed in terms of NIDDK mFSH-RP (AFP-5308D) and NIDDK mLH-RP (AFP-5306A). The iodination preparations were iodinated using Iodogen reagent (Pierce, Rockford, Ill., USA). Goat anti-rabbit IgG (GAR\#12 - Monash Institute of Medical Research, Monash University, Melbourne, Vic., Australia) was used as second antibody for the FSH and LH radioimmunoassays. The lower limits of detection were $1.83 \mathrm{ng} /$ $\mathrm{ml}(\mathrm{FSH})$ and $0.13 \mathrm{ng} / \mathrm{ml}(\mathrm{LH})$. The within-assay \% coefficients of variances were $8.0 \%(\mathrm{FSH})$ and $4.8 \%(\mathrm{LH})$. Testosterone was measured using a commercial radioimmunoassay kit (DSL-4100; Diagnostic Systems Laboratories, Webster, Tex., USA) according to manufacturer's instructions. The lowest limit of detection was $0.094 \mathrm{ng} / \mathrm{ml}$ and the within-assay \% coefficient of variance was $4.2 \%$. All samples were measured in a single assay for each hormone.

\section{Reverse Transcription PCR (RT-PCR)}

Total RNA was isolated from fetal and adult mouse gonads using RNeasy Mini kit (Qiagen, Valencia, Calif., USA) and treated with DNaseI using DNA-free (Ambion, Austin, Tex., USA). $1 \mu \mathrm{g}$ of DNaseI-treated RNA was reverse transcribed using random hexamers and 10 units of Transcriptor High Fidelity Reverse Transcriptase (Roche, Mannheim, Germany) according to manufacturers' instructions. To determine the expression level of Redd1, 50 ng of cDNA was subject to multiplex PCR using primers specific for Redd1 (fwd: 5'-GCACCAGTTCGCTCACCCTT-3' and rev: 5'-GGCACACAGGTGCTCATCCT-3') and Hprt (hypoxanthine guanine phosphoribosyl transferase, NM_013556) (fwd: 5'-TGCTGACCTGCTGGATTACA-3' and rev: 5'-GCTTAACCAGGGAAAGCAAAG-3').

Characterisation of Redd1-Deficient Mice

\section{Quantitative Real-Time PCR (qPCR)}

For experiments using $\mathrm{CDNA}$ isolated from pure cell populations, testes were dissected from Oct4-GFP transgenic mice and germ and somatic cell populations were separated by fluorescence activated cell sorting (FACS) as described previously [Western et al., 2008]. qPCR was performed in triplicate using up to $50 \mathrm{ng}$ cDNA in each $10-\mu$ l reaction, using the mouse Universal Probe Library (UPL) system (Roche), LightCycler 480 Probes Master (Roche) and a LightCycler 480 instrument (Roche). Relative expression was determined using the comparative $\mathrm{C}_{\mathrm{T}}$ method $\left(\Delta \Delta \mathrm{C}_{\mathrm{T}}\right)$ [Livak and Schmittgen, 2001], with samples normalised against Sdha (succinate dehydrogenase complex, subunit A, flavoprotein) and expressed relative to the sample showing the highest level of expression for each experiment. Primers for Redd1, Redd2 (NM_030143) and Sdha (NM_023281) were designed using the UPL Assay Design Centre (https://www.roche-applied-science. com/sis/rtpcr/upl/adc.jsp).

\section{Fertility Study}

The fertility of Redd1-deficient males and females aged 7-11 weeks, was assessed by matings with wild-type female and male mice, respectively. At least 6 different breeding pairs were set up for each group. The number of pups born per litter, the percentage of pups weaned per litter and the percentage of males weaned per litter were recorded. The effect of genotype on group means for pups born/litter and pups weaned/litter was analysed by one-way analysis of variance. The effect of genotype on percentage of male offspring per total number of mice born was analysed by $\chi^{2}$ analysis.

\section{Results}

\section{Redd1 Is Differentially Expressed during Embryonic} and Adult Gonad Development

We previously identified Redd1 as a novel gene that is differentially expressed in the developing mouse gonad at the time of sex determination, with higher expression in testis than ovary [McClive et al., 2003]. In the present study, differential expression of Redd 1 in male and female gonads from 11.5 to $16.5 \mathrm{dpc}$ was confirmed by WISH (fig. 1A-H). Redd 1 expression in the testis was maintained throughout gonad development (fig. 1A-D) and was localised within the cords from $12.5 \mathrm{dpc}$ (fig. 1B-D). Expression was also observed in the Wolffian and Müllerian ducts in both male and female embryos (fig. 1B and G). In the ovary, weak Redd1 expression was observed from 11.5 dpc (fig. 1E-H). We next compared temporal expression of Redd1 and Sry using tail somite (ts) staged testis pairs. Redd1 mRNA expression was first detected just as Sry expression peaked at 19 ts (fig. 1I-P) and immediately prior to morphological sex determination, suggesting that Redd 1 could be involved downstream in the Sry pathway. We also examined Redd1 expression levels in adult versus embry- 
Fig. 1. Expression analysis of Redd1 during mouse gonadogenesis. A-H Temporal expression analysis of Redd1 by WISH. A-D Male and E-H female gonads at 11.5 $\mathrm{dpc}, 12.5 \mathrm{dpc}, 13.5 \mathrm{dpc}$ and $16.5 \mathrm{dpc}$. Dotted lines show the mesonephric-gonadal boundaries. $\mathrm{md}=$ Müllerian duct; $\mathrm{wd}=$ Wolffian duct. I-P Temporal expression analysis of Redd1 versus Sry in left and right gonad pairs by WISH. I-L Sry and M-P Redd1 expression at 11 tail somites (ts), 19 ts, 20 ts and 21 ts. Bars $=500 \mu \mathrm{m}$. $\mathbf{Q}$ qPCR analysis of Redd1 cDNA expression (normalised against $S d h a$ and relative to $12.5 \mathrm{dpc}$ testis) in whole gonads from $12.5 \mathrm{dpc}$ embryos and 8-week-old mature mice. Fetal gonads were pooled according to sex (1 litter per pool). Values are mean $\pm \operatorname{SEM}(\mathrm{n}=3)$.
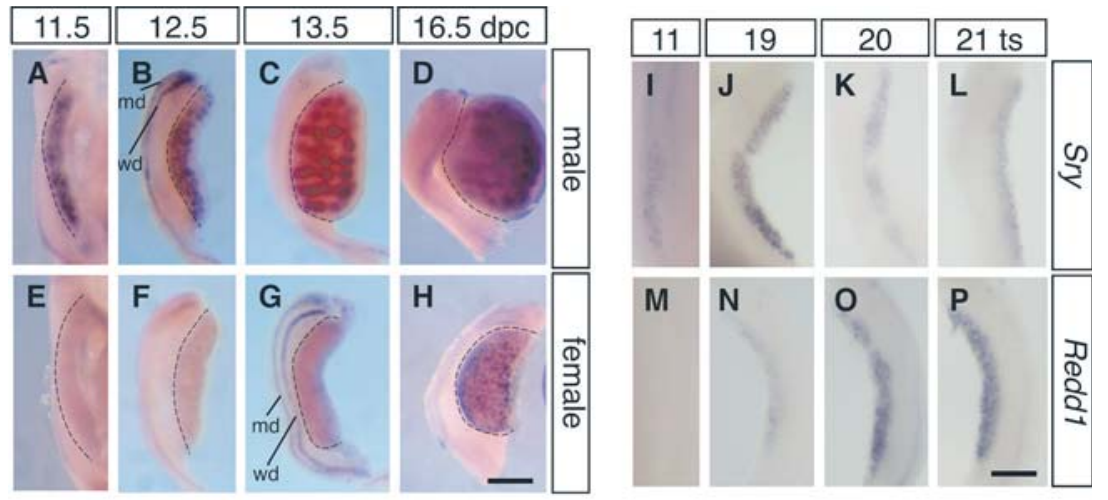

Q

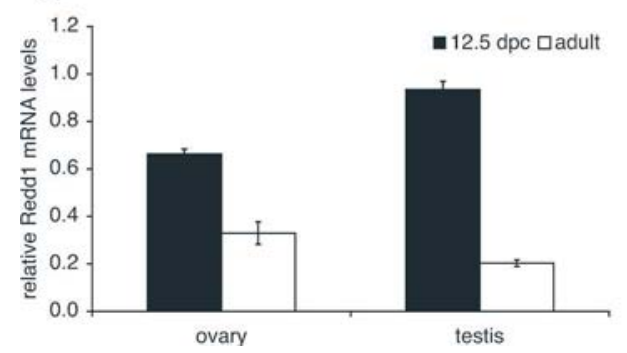

onic gonads by qPCR. Differential expression of Redd 1 at $12.5 \mathrm{dpc}$ was confirmed using this approach. Furthermore, we observed a reduction in the expression levels of Redd1 in the adult gonad compared to the embryonic gonad (fig. 1Q). These results indicate that Redd1 may be important at various stages during testis development.

\section{Redd1 Is Expressed in Pre-Sertoli and Germ Cells}

In order to identify which cell types within the developing testis cords express Redd1, we performed WISH on $12.5 \mathrm{dpc}$ male gonads. Sections from WISH analysis demonstrated that within the developing testis, Redd1 expression is confined to the testis cords indicating that Redd1 is expressed by the Sertoli and/or germ cells (fig. 2A, B). The expression of Redd1 in somatic and germ cell populations was ascertained by qPCR using sorted cell populations derived from the testes of Oct4GFP transgenic mice. We have previously demonstrated the sorted cell populations to be $99 \%$ pure by FACS analysis and qPCR using germ- and somatic cell-specific markers [Western et al., 2008]. In this study, we found that Redd1 expression was detected in both the somatic and germ cell populations between 12.5 and $15.5 \mathrm{dpc}$ (fig. 2C). The level of Redd1 expression in the germ cell populations at 12.5 and $13.5 \mathrm{dpc}$ was as high or higher than the levels in the somatic cell population (fig. 2C), suggesting that Redd1 may also play a role in germ cell development.

\section{Generation and Validation of Redd1-Deficient Mice}

To investigate the function of Redd1, mice carrying a Redd 1 floxed allele (fig. 3A) were generated by standard gene targeting techniques. Offspring resulting from matings between floxed Redd1 chimeric males and PGK-Cre transgenic mice were screened by Southern analysis to confirm germline transmission (fig. 3B). Heterozygous Redd1-deficient mice carrying PGK-Cre were backcrossed to $\mathrm{C} 57 \mathrm{BL} / 6$ to remove the Cre transgene. Heterozygous Redd1-deficient mice (negative for $\mathrm{Cre}$ ) were intercrossed and the resulting progeny were genotyped by PCR. Using this approach, we observed that heterozygous Redd1-deficient matings produced offspring with a normal Mendelian distribution of genotypes (data not shown). Furthermore, Redd1-deficient mice were grossly indistinguishable from littermate controls, suggesting that Redd 1 does not play a critical role in embryonic or neonatal development. Multiplex RT-PCR on total testis cDNA from wild-type and heterozygous Redd1-deficient mice resulted in a 402-bp band corresponding to Redd1 cDNA and a 230-bp band corresponding to Hprt cDNA (fig. 3C). In 

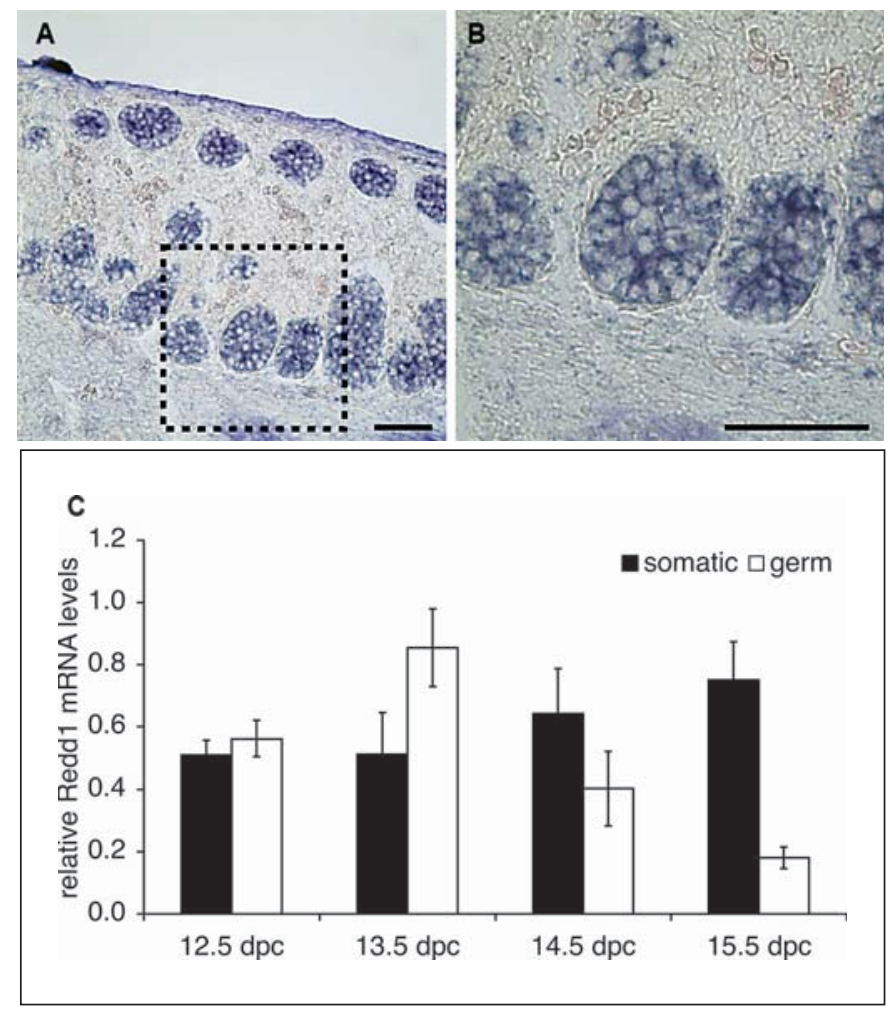

Fig. 2. Redd1 is expressed in both Sertoli and germ cell populations. A, B Overstained and sectioned WISH of $12.5 \mathrm{dpc}$ wild-type testis. Redd1 expression is localised to the testis cords, indicative of a Sertoli and/or germ cell expressed transcript. Bars $=50 \mu \mathrm{m}$. C qPCR analysis of Redd1 cDNA expression (normalised against $S d h a$ and relative to $13.5 \mathrm{dpc}$ germ cell population) in pure germ cell populations and somatic cell populations, sorted from the testes of 12.5 to $15.5 \mathrm{dpc} O c t 4-G F P$ transgenic mice. Values are mean $\pm \mathrm{SD}$ for pooled samples $(\mathrm{n}=3)$ measured in triplicate.

contrast, only the 230-bp Hprt band could be amplified from Redd1-deficient mice (fig. 3C), verifying that Cremediated deletion of the floxed Redd1 allele was complete.

\section{Redd1-Deficient Mice Display Normal Fetal Testis Development}

H\&E-stained testis sections from $14.5 \mathrm{dpc}$ wild-type and Redd1-deficient mice showed no obvious differences in cord formation or testis development (fig. 4A, B). Furthermore, no gross differences in general tissue organisation or cellular composition were observed following immunofluorescence on $14.5 \mathrm{dpc}$ testes with cell-type-specific markers for WT1 (Sertoli cells), laminin (basement cell membrane), P450scc (Leydig cells) and MVH (germ cells) (fig. 4C-J).

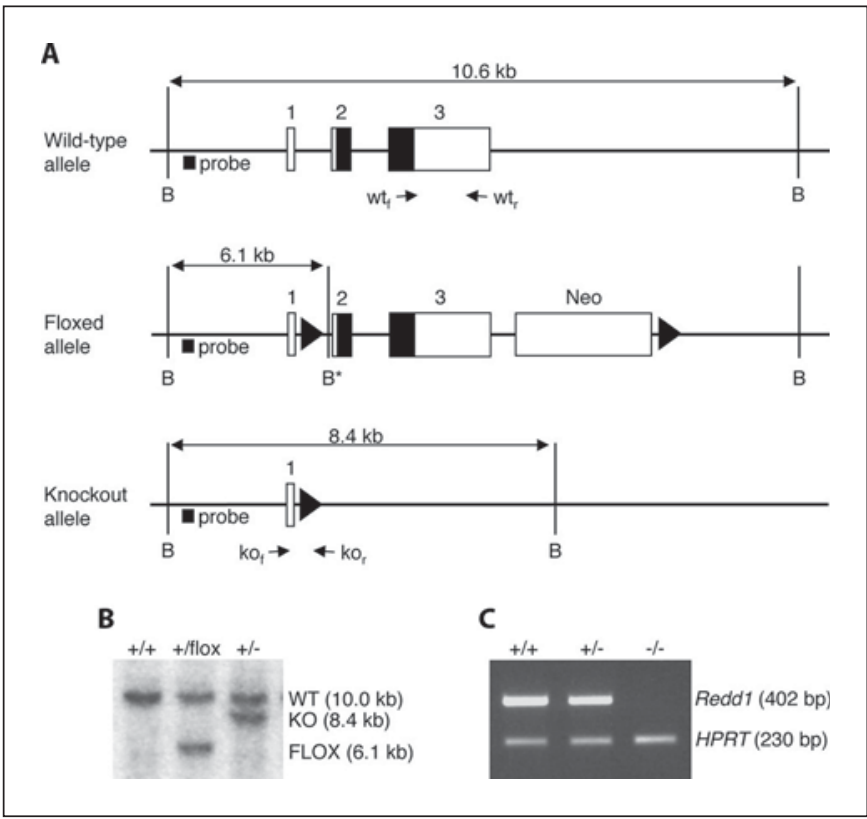

Fig. 3. Generation of Redd1-deficient mice. A Schematic diagram of wild-type, floxed and Redd1 knockout alleles. Redd1 is comprised of 3 exons (numbered 1 to 3 ) and the ATG is located within exon 2. LoxP sites are represented as black triangles. The position of the 450-bp $5^{\prime}$ probe used for Southern blotting and the primers $\left(\mathrm{wt}_{\mathrm{f}}, \mathrm{wt}_{\mathrm{r}}, \mathrm{ko}_{\mathrm{f}}, \mathrm{ko}_{\mathrm{r}}\right)$ used for PCR genotyping are indicated. $\mathrm{B}=B g l \mathrm{II}$ restriction site; $\mathrm{B}^{*}=$ newly created $B g l \mathrm{II}$ restriction site. B Southern blot analysis of wild-type $(+/+)$, heterozygous floxed (+/flox) and heterozygous knockout (+/-) mice using BglII-digested tail DNA and the 450-bp 5' probe to confirm germline transmission. C RT-PCR using total testis cDNA from wild-type, heterozygous knockout and homozygous knockout adult mice. Redd1 primers generate a 402-bp band and Hprt primers generate a 230-bp band.

\section{Redd1-Deficient Mice Are Fertile}

Both Redd1-deficient males and females demonstrated normal fertility with respect to the number of pups born per litter, the proportion of pups weaned per litter and the percentage of males weaned per litter (table 1). No cases of ambiguous genitalia or sex reversal were observed among the offspring. Furthermore, serum LH, FSH and testosterone levels were normal in Redd1-deficient adult males (table 2).

\section{Redd2 Is Expressed in the Somatic Cells during Early \\ Testis Development}

The possibility of functional redundancy by Redd2 (a Redd1 paralogue) was investigated as an explanation for the mild phenotype in our knockout model. The levels of Redd 2 expression in sorted somatic and germ cell popula- 

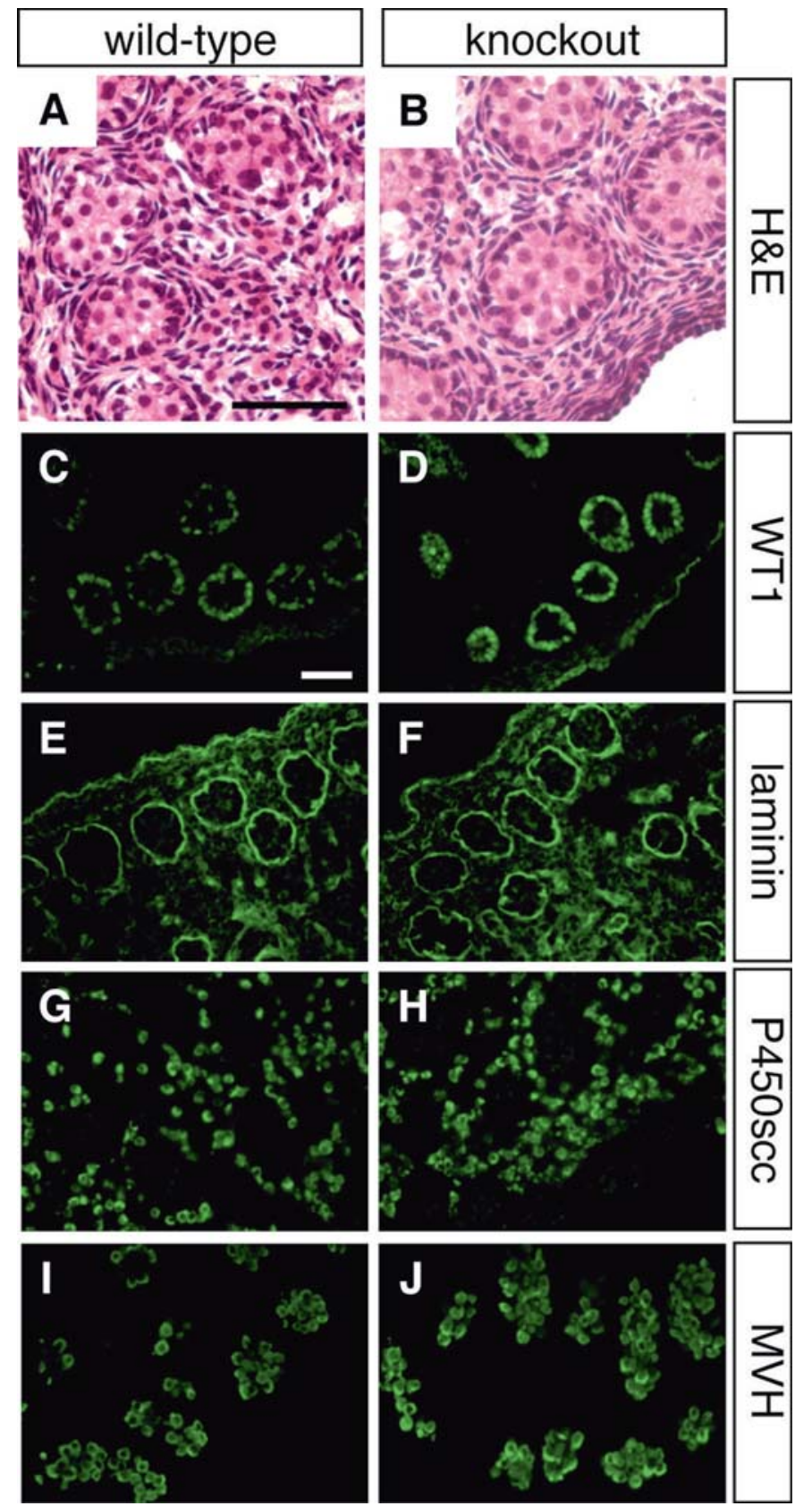

Fig. 4. Immunofluorescence of wild-type and Redd1-deficient male gonads. Wild-type (A, C, E, G, I) and homozygous Redd1deficient (B, D, F, H, J) fetal mouse testis sections at $14.5 \mathrm{dpc}$ stained with $\mathrm{H} \& \mathrm{E}$ and immunofluorescence performed with WT1 (a Sertoli cell marker), laminin (a basement cell membrane marker), P450scc (a Leydig cell marker) and MVH (a germ cell marker). Bars $=50 \mu \mathrm{m}$.

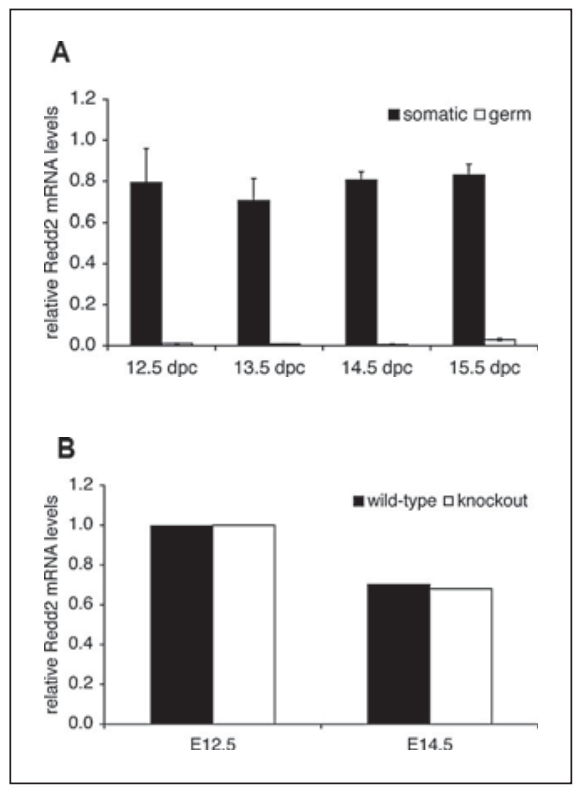

Fig. 5. qPCR analysis of Redd2 in wild-type and Redd1-deficient male gonads. A qPCR analysis of Redd 2 cDNA levels (normalised against $S d h a$ and relative to $12.5 \mathrm{dpc}$ somatic cell population) in pure germ cell and somatic cell populations, sorted from the testes of 12.5 to $15.5 \mathrm{dpc}$ Oct4-GFP transgenic mice. Values are mean \pm SEM for pooled samples $(n=3)$ measured in triplicate. B qPCR analysis of Redd2 cDNA levels (normalised against Sdha and relative to $12.5 \mathrm{dpc}$ knockout sample) in wild-type and Redd1-deficient whole gonads at 12.5 and $14.5 \mathrm{dpc}$. Fetal gonads were pooled according to sex and stage (1 litter per pool) and each sample was measured in triplicate. Values represent the mean of technical triplicates.

tions were ascertained by qPCR. Redd 2 expression was detected exclusively in the somatic cell populations between 12.5 and $15.5 \mathrm{dpc}$ (fig. 5A), suggesting that this gene may compensate for Redd1 loss in the supporting cell lineage, but not in germ cells. We also performed qPCR to determine the levels of Redd2 in Redd1-deficient gonads compared to wild-type controls at $12.5 \mathrm{dpc}$ and $14.5 \mathrm{dpc}$. Fetal gonads were pooled according to sex and stage (1 litter per pool) and each sample was measured in triplicate. qPCR analysis revealed no change in the level of Redd 2 expression in Redd1-deficient gonads compared to controls at either stage (fig. 5B).

\section{Discussion}

Causative mutations in known sex-determining genes such as SRY account for approximately $20 \%$ of human XY male-to-female sex reversal cases. In the remaining $80 \%$ 
Table 1. Reproductive phenotype of Redd1-deficient mice

\begin{tabular}{lclll}
\hline $\begin{array}{l}\text { Mating } \\
(\text { male } \times \text { female })\end{array}$ & $\begin{array}{l}\text { Number of days until first } \\
\text { litter }^{\mathrm{a}}(\mathrm{n})\end{array}$ & Pups born/litter ${ }^{\mathrm{a}}(\mathrm{n})$ & Pups weaned/litter, \% $^{\mathrm{a}}(\mathrm{n})$ & $\begin{array}{l}\text { Males weaned } \\
(\%)\end{array}$ \\
\hline Wild-type $\times$ wild-type & $20.7 \pm 0.9(6)$ & $7.6 \pm 0.4(17)$ & $74.3 \pm 7.2(17)$ & $45 / 96(46.9)$ \\
Redd1 $^{-/-} \times$wild-type & $26 \pm 2.9(14)$ & $7.3 \pm 0.5(29)$ & $74.8 \pm 6.6(29)$ & $83 / 171(48.5)$ \\
Wild-type $\times$ Redd1 $^{-/-}$ & $28.4 \pm 6.7(5)$ & $7.2 \pm 0.5(19)$ & $69.5 \pm 7.2(19)$ & $48 / 99(48.5)$ \\
\hline
\end{tabular}

${ }^{a}$ Values are mean \pm SEM. $n=$ Number of litters analysed per group. $\mathrm{p}>0.05$, calculated using one-way analysis of variance.

${ }^{b}$ Values are number of males/number of pups weaned. $\mathrm{p}>0.05$, calculated using $\chi^{2}$ analysis.

Table 2. Serum hormone measurements of Redd1-deficient mice

\begin{tabular}{llll}
\hline Genotype & LH, ng/ml & FSH, ng/ml & Testosterone, ng/ml \\
\hline Redd1 $1^{+/+}$ & $0.20 \pm 0.01$ & $9.6 \pm 0.4$ & $1.0 \pm 1.6$ \\
Redd1 $1^{-/-}$ & $0.18 \pm 0.00$ & $9.1 \pm 0.2$ & $1.9 \pm 13.9$ \\
\hline
\end{tabular}
group.

All values are mean \pm SEM. Ten mice were analysed per

of cases, mutations in known sex-determining genes have not yet been found, suggesting that other, as yet unidentified genes are likely to play an important role in the sex determination/differentiation pathway. We previously used a suppression subtraction hybridisation screen to identify novel sexually dimorphic genes expressed in the mouse gonad at the time of sex determination [McClive et al., 2003]. One gene revealed by our screen was Redd1, a recently cloned stress response gene. We present here a detailed analysis of Redd1 expression during mouse gonadogenesis and functional analysis of a mouse model with targeted disruption of this gene.

Expression analysis using WISH and qPCR revealed higher levels of Redd1 expression in the testis than in the ovary at $12.5 \mathrm{dpc}$. Furthermore, expression localised to the pre-Sertoli and germ cells of the testis cords and was upregulated immediately following peak Sry expression. Based on the temporal and spatial expression pattern observed for Redd1, we investigated the functional importance of this gene during gonadogenesis. To our surprise, Redd1-deficient mice were grossly indistinguishable from littermate controls and showed normal fertility. Fetal testis development appeared normal with respect to cord formation, cell composition and expression of cell typespecific markers. No differences in hormone production were detected in Redd1 null mice and the litter sizes and sex ratios of offspring born to knockout mice were also normal. Interestingly, although we observed no phenotypic differences in the cellular composition or reproductive function of testes in Redd1 null mice, there appeared to be a small $(<20 \%)$ increase in testis weight, compared to wild-type controls. The significance of this difference remains unknown, but is consistent with a role for Redd1 in controlling testis growth.

One explanation for the normal reproduction and fertility of Redd1-deficient mice may be the potential for Redd2 to functionally compensate for the loss of Redd1. A study in Drosophila has revealed the functional redundancy of scylla and charybdis (Redd1/Redd2 orthologues) for head involution during larval development [Scuderi et al., 2006]. In this study, we demonstrate that Redd2 is expressed exclusively in the somatic cells of the developing gonad, although further investigation is required to determine the precise somatic cell type(s) that expresses Redd2. Since Redd1 is expressed in both somatic and germ cells of the developing testis, this data implies that if Redd 2 can compensate for loss of Redd1, this compensation is restricted to the somatic cell compartment and any effect on germ cell development is indirect.

A double knockout of Redd1 and Redd 2 may reveal a more pronounced phenotype and role for these genes during testis development.

\section{Acknowledgements}

We would like to thank members of our laboratories for valuable discussions; Anne O'Connor for serum hormone measurements; and Anna Piper and Christine Hall for animal husbandry. This research was supported by The National Health and Medical Research Council (Program Grant \#334314) and the Victorian Government's Operational Infrastructure Support Program. 


\section{References}

Andrews JE, Smith CA, Sinclair AH: Sites of estrogen receptor and aromatase expression in the chicken embryo. Gen Comp Endocrinol 108:182-190 (1997).

Brugarolas J, Lei K, Hurley RL, Manning BD, Reiling JH, et al: Regulation of mTOR function in response to hypoxia by REDD1 and the TSC1/TSC2 tumor suppressor complex. Genes Dev 18:2893-2904 (2004).

Corradetti MN, Inoki K, Guan KL: The stressinducted proteins RTP801 and RTP8011 are negative regulators of the mammalian target of rapamycin pathway. J Biol Chem 280: 9769-9772 (2005).

-Eicher EM, Washburn LL, Schork NJ, Lee BK, Shown EP, et al: Sex-determining genes on mouse autosomes identified by linkage analysis of C57BL/6J-Y ${ }^{\mathrm{POS}}$ sex reversal. Nat Genet 14:206-209 (1996).

-Ellisen LW, Ramsayer KD, Johannessen CM, Yang A, Beppu $\mathrm{H}$, et al: REDD1, a developmentally regulated transcriptional target of p63 and p53, links p63 to regulation of reactive oxygen species. Mol Cell 10:995-1005 (2002).

- Gery S, Park DJ, Vuong PT, Virk RK, Muller CI, et al: RTP801 is a novel retinoic acid-responsive gene associated with myeloid differentiation. Exp Hematol 35:572-578 (2007).
Hurley TM, McClive PJ, Sarraj MA, Sinclair AH: Eki2 is upregulated specifically in the testis during mouse sex determination. Gene Expr Patterns 4:135-140 (2004).

Köntgen F, Süss G, Stewart C, Steinmetz M, Bluethmann H: Targeted disruption of the MHC class II Aa gene in C57BL/6 mice. Int Immunol 5:957-964 (1993).

Koopman P, Munsterberg A, Capel B, Vivian N, Lovell-Badge R: Expression of a candidate sex-determining gene during mouse testis differentiation. Nature 348:450-452 (1990).

Livak KJ, Schmittgen TD: Analysis of relative gene expression data using real-time quantitative PCR and the 2(-Delta Delta C(T)) method. Methods 25:402-408 (2001).

McClive PJ, Sinclair AH: Type II and type IX collagen transcript isoforms are expressed during mouse testis development. Biol Reprod 68:1742-1747 (2003).

McClive PJ, Hurley TM, Sarraj MA, van den Bergen JA, Sinclair AH: Subtractive hybridisation screen identifies sexually dimorphic gene expression in the embryonic mouse gonad. Genesis 37:84-90 (2003).
Reiling JH, Hafen E: The hypoxia-induced paralogs Scylla and Charybdis inhibit growth by down-regulating S6K activity upstream of TSC in Drosophila. Genes Dev 18:2879-2892 (2004).

Scuderi A, Simin K, Kazuko SG, Metherall JE, Letsou A: Scylla and charybde, homologues of the human apoptotic gene RTP801, are required for head involution in Drosophila. Dev Biol 291:110-122 (2006).

Shoshani T, Faerman A, Mett I, Zelin E, Tenne T, et al: Identification of a novel hypoxia-inducible factor 1-responsive gene, RTP801, involved in apoptosis. Mol Cell Biol 22:22832293 (2002).

- Sinclair AH, Berta P, Palmer MS, Hawkins JR, Griffiths BL, et al: A gene from the human sex-determining region encodes a protein with homology to a conserved DNA-binding motif. Nature 346:240-244 (1990).

Wang Z, Malone MH, Thomenius MJ, Zhong F, $\mathrm{Xu}$ F, Distelhorst CW: Dexamethasone-induced gene 2 (dig2) is a novel pro-survival stress gene induced rapidly by diverse apoptotic signals. J Biol Chem 278:27053-27058 (2003).

-Western PS, Miles DC, van den Bergen JA, Burton M, Sinclair AH: Dynamic regulation of mitotic arrest in fetal male germ cells. Stem Cells 26:339-347 (2008) 